\title{
OJED
}

ISSN: 2166-2681 Print/ 2690-0408 Online Volume 9, Issue 2 (2020), pp.i-iv

(C) Journal of Interdisciplinary Studies in Education http://ojed.org/jise

\section{Remote Learning and Foregoing the Dream}

\author{
Stephen Kotok \\ St. John's University, USA
}

Due to Covid-19, almost all public-school districts across the U.S. suspended in-person learning and shifted over night to remote learning. I am writing this in May of 2020. The future of the pandemic is unclear. However, we need to think critically how this challenging time informs post-Covid educational policies and curriculum. School choice advocates- especially proponents of home school and virtual charter schools- point to success stories of students who continued to learn at high levels during the pandemic or tout the efficiency of online delivery in terms of time and monetary costs (Barbour, 2012). Conversely, many scholars point out that the various pedagogical and equity issues result in low-academic achievement and large opportunity gaps (Ahn \& McEachin, 2017; Mann \& Kotok, 2019; Woodworth et al., 2015). As these debates persist, we also need to consider purposes of schooling related to socialization and civic responsibility (Banks, 1997). Students benefit greatly academically and socially from physically attending schools with diversity in race/ethnicity, language, and even different political views (Kotok \& DeMatthews, 2018; Campbell, 2008; Carter, 2009; Mickelson \& Nkomo, 2012) and it is unclear if remote learning offers the same level of interaction needed to foster meaningful relationships. I contend it is more important than ever to return to in-person learning experiences when we can while integrating digital technology as a supplement rather than a replacement.

Research finds that students learn more when working alongside students of different socioeconomic and racial backgrounds (Coleman et al., 1966; Johnson, 2019; Wells, Fox, \& Cordovo-Cobo, 2016), but remote learning limits genuine peer interaction. Theoretically, students can interact with different peers virtually, but these remote experiences differ drastically from students sitting in a class together (Mann, 2019). As the parent of a $2^{\text {nd }}$ 
grader, I have witnessed the difficulty of creating interactive digital learning experiences. Although my daughter's teacher and teachers all around the U.S. have done a great job of mobilizing to provide individualized learning experiences, the on-line classroom is mostly devoid of peer-to-peer interaction. Some video conferencing platforms allow break out rooms, but younger children require more assistance in logging in and transitioning to different online learning spaces, putting unrealistic demands on the teacher and/or parents of the children. Adolescent students can handle these break out groups easier than younger students, but we again run into issues of the digital divide and access as some students share devices with siblings and rely on slower Wi-Fi.

Another important aspect of schooling involves community and civic engagement (Pai \& Adler, 2001). Putnam (2000) famously commented that Americans are increasingly "bowling alone" rather than joining leagues as a metaphor for a changing civil society. Although Americans may engage in political discourse on Facebook rather than the local Elks club or church, something is lost when people - including students - only interact digitally. The "Black Lives Matter" and the "March for Our Lives Rallies" serve as powerful examples of grassroots movements that took advantage of digital media (Bodovski, 2019). However, our increasingly polarized society in the U.S. means an over reliance on digital platforms results in gravitating to your bubble rather than freely exchanging ideas. In my own experience attending one of the most racially and economically integrated high schools in my state, these interchanges of views often took place at lunch, in between classes, and playing basketball during gym in addition to structured classrooms.

Despite my criticism of full-time remote learning, it also introduces some supplemental opportunities for people of different backgrounds to interact virtually. Mann (2019) points out that virtual school districts could be designed to serve large diverse student bodies, but such an arrangement would be difficult in a country such as the U.S. with hyper-localized funding and curriculum. Moreover, massive on-line education further isolates students from their own communities and runs counter to other goals of civic engagement. A better alternative is to seek hybridized learning opportunities that build off of a strong in-person school community. A few years back, I toured a school in New Jersey where the Spanish class consisted of video conferencing with a peer English class in Madrid, Spain. In this case, video conferencing opened a new opportunity rather than replacing the school community.

After we get through the pandemic, I fear that some school districts may be tempted to use their new found technology to offer an online option or that increasing amounts of parents may seek online charter options. I am reminded of a quote by the late, Dr. Martin Luther King Jr. who said, "The function of education is to teach one to think intensively and to think 
critically. But education which stops with efficiency may prove the greatest menace to society. The most dangerous criminal may be the man gifted with reason but no morals. ... We must remember that intelligence is not enough. Intelligence plus character - that is the goal of true education." Although chat rooms and educational apps pass the efficiency test, I do not think they provide enough for our children

\section{REFERENCES}

Ahn, J., \& McEachin, A. (2017). Student enrollment patterns and achievement in Ohio's online charter schools. Educational Researcher, 46(1), 44-57.

Banks, J. A. (1997). Educating citizens in a multicultural society. Teachers College Press.

Barbour, M. K. (2012). Are virtual schools more cost-effective compared to traditional, brick- and-mortar schools?" Technology in schools: Debating issues in American education. Ed. K. P. Brady: Sage.

Bodovski, K. (2019). Childhood and education in the United States and Russia: Sociological and comparative perspectives. Emerald Publishing.

Campbell, D. E. (2008). Voice in the classroom: How an open classroom climate fosters political engagement among adolescents. Political Behavior, 30(4), 437-454.

Carter, P. (2009). Equity and empathy: Toward racial and educational achievement in the Obama era. Harvard Educational Review, 79(2), 287-297.

Coleman, J. S., Campbell, E. Q., Hobson, C. J., McPartland, J., Mood, A. M., Weinfeld, F., \& York, R. L. (1966). Equality of educational opportunity (Report No. OE- 3800). Washington, DC: National Center for Educational Statistics.

Johnson, R. C. (2019). Children of the dream: Why school integration works. Basic Books.

Kotok. S., \& DeMatthews, D. (2018). Challenging school segregation in the $21^{\text {st }}$ century: How districts can leverage dual language education to increase school and classroom diversity. The Clearinghouse: A Journal of Educational Strategies, Issues, and Ideas, 91(1), 1-6.

King Jr, M. L. (1947). The purpose of education. The maroon tiger, 10, 123-124.

Mann, B. \& Kotok, S. (2019). Stratified Choices: How market assumptions and performance outcomes relate to cyber charter enrollments. Teachers College Record, 121(3), 1-11.

Mann, B. (2019). Whiteness and economic advantage in digital schooling: Diversity patterns and equity considerations for K-12 online charter schools. Education Policy Analysis Archives, 27, 105.

Mickelson, R. A., \& Nkomo, M. (2012). Integrated schooling, life course outcomes, and social cohesion in multiethnic democratic societies. Review of Research in Education, 36(1), 197-238.

Pai, Y., \& Adler, S. A. (2001). Cultural foundations of education (3rd edn). Prentice Hall. 
Putnam, R. D. (2000). Bowling alone: The collapse and revival of American community. Simon and Schuster.

Wells, A. S., Fox, L., \& Cordova-Cobo, D. (2016). How racially diverse schools and classrooms can benefit all students. The Education Digest, 82(1), 17.

Woodworth, J. L., Raymond, M. E., Chirbas, K., Gonzalez, M., Negassi, Y., Snow, W., \& Van Donge, C. (2015). Online charter school study 2015. Center for Research on Educational Outcomes. Available at https://credo. stanford. edu/pdfs/Online\% 20Charter\% 20Study20Final. pdf, 165.

Stephen Kotok is an assistant professor in the Department of Administrative and Instructional Leadership at St. John's University. His research focuses on the opportunity gap for low-income and minority students and how school context affects these disparities. Specifically, Kotok examines equity-based school improvement strategies related to school climate and detracking as well as policy-level issues such as school choice, resource allocation, and segregation. Prior to joining St. John's University, he was a member of the administrative team at Hope Academy Charter School in Asbury Park, NJ, and was a social studies teacher with the School District of Philadelphia. Email: kotoks@stjohns.edu 